\title{
LEUKOCYTE PROFILE OF BLOOD OF COWS AT USING "LEUCOZAV" AGAINST LEUCOSIS OF CATTLE
}

\author{
Ganna Zaviriyha \\ Department of microbiology \\ State Center of Innovatione Biotechnologies \\ 30 Donetska str., Kyiv, Ukraine, 03151 \\ annazavir@gmail.com \\ Oleg Vishchur \\ Department of immunology \\ Institute of Animal Biology NAAS \\ 38 V. Stus str. Lviv, Ukraine, 79034 \\ vishchur_oleg@ukr.net \\ TetyanaVasileva \\ Department of microbiology \\ State Center of Innovatione Biotechnologies \\ 30 Donetska str., Kyiv, Ukraine, 03151 \\ tanya.vasyleva@gmail.com

\section{Uíjana Yanenko} \\ Department of molecular genetic research, virology and immunology \\ State Center of Innovatione Biotechnologies \\ 30 Donetska str., Kyiv, Ukraine, 03151 \\ ulyanakuzyk@ukr.net \\ Lydmila Balabuha \\ Department of microbiology \\ State Center of Innovatione Biotechnologies \\ 30 Donetska str., Kyiv, Ukraine, 03151 \\ dnu.cib@ukr.net \\ Oleksandr Balaban \\ Department of biotechnology \\ State Center of Innovatione Biotechnologies \\ 30 Donetska str., Kyiv, Ukraine, 03151 \\ aleks2291.5050@gmail.com
}

Abstract

The development of specific medical forms for fighting against the tumor disease (cancer) of people and animals has the extremely important value. The preparation "ZG-2011" ("Leucozav") was invented in 2000-2006 by research associates of SSI "State center of innovative biotechnologies" that forms in inoculated animals the specific anti-viral immunity that protects cattle from being infected by the leucosis causative agent. Analogues of this preparation in Ukraine are absent.

The main aim of the study is the determination of "Leucozav" influence on morphologic parameters of blood (leukocyte profile) of clinically healthy cows and ones, infected by leucosis.

The object of the study was blood of cattle (milk herd), considered as unfavorable as to leucosis.

Blood samples were studied before administering "Leucozav" and after that. Serological and immunological research methods were used.

At the experiment it was studied, that "Leucozav" administration to infected animals normalizes leukocytes number and the ratio of their separate forms in blood of cows. In blood samples, taken of healthy cows, the preparation administration doesn't influence the leukocyte profile. 
This experiment gives grounds to recommend the newly created preparation "Leucozav" to cows with leucosis, because it normalizes the number of leukocytes and their ration in separate forms in blood of RID-positive cows that react positively at the immune diffusion reaction in the agar gel at the study of leucosis of cattle.

Keywords: cattle, leucosis agent, immune-modeling preparation, leukocyte profile. Uliana Yanenko, Lydmila Balabuha, Oleksandr Balaban

\section{Introduction}

Leucosis of cattle is a chronic disease of the malignant timorous nature with mainly latent development of the infectious process. The agent - RNA-containing virus of Retroviridae family, Deltaretrovirus genus [1]. Today the role of the virus in disease appearance on farm, domestic and laboratory animals is proved by the essential number of experimental works and cannot be objected [2].

The virus of leucosis of cattle is a retrovirus, closely connected with the human T-lymphotropic virus type 1 (HTLV-1). BLV - Bovine leukemia virus - virus of bovine leukemia is the main problem of animal health throughout the world that causes essential economic losses. There was realized the series of attempts to decrease its prevalence, mainly by elimination of infected cattle, segregation of animals without BLV and vaccination. Despite having played an important role in such regions as EU these strategies turned out unsuccessful in other countries, mainly because of economic losses, limitations of management and absence of the effective vaccine [3].

Last time the idea about the possible commonness of the virus of cattle leucosis (VL C) and the one of human leucosis prevails. The similarity of the virus of cattle leucosis to T-lymphotropic virus of primates (STLV type 1, 2, 3) and virus of T-cellular human leukemia (HTLV type 1 i 2) was established. In human were separated four retroviruses, type 1-4 (HTLV-1-4). Among them HTLV-1 hits near $20 \mathrm{mln}$ people throughout the world, the part of which (near 2-3\%) causes the development of the acute T-cellular leukemia (ATL) or HTLV-associated myelopathy/tropic spastic paraparesis (HAM/TSP) [4]. Micro-RNA of the cattle virus is intensely expressed in malignant tumors, which structural and regulatory genes expression is repressed that indicates the node role in the tumor start and progression [5].

Cattle leucosis relates to the group of hemoblastosis that is neoplasms, developed from cells of the blood-forming tissue. Leucosis occupies the first place among diseases of the human blood system. It has an essential social importance because of high mortality that is near $6-10 \%$ of adults and near $50 \%$ of children, who die from malignant neoplasms. The mortality from leucosis is near $1 \%$ of the general mortality in all world countries.

The following directions are studied for today: a) revelation of biological mechanisms of transformation of a normal cell into malignant one; b) elucidation of immunologic features at timorous diseases; c) creation of reliable methods of leucosis diagnostics; d) study of VL C persistence of biochemical processes in the organism of infected animals. The study of changes of adhesive properties of cells at their development belongs to node questions of oncology and attracts more and more attention of researchers [6]. Persistence of the leucosis agent is studied mainly on hematologically infected animals or ones with the positive serological reaction by RID [7]. The studies were realized to investigate morphological, functional, immunological and biochemical changes of the cattle leucosis pathogenesis [8]. It was established, that the state of immunodeficiency in infected animals develops in parallel with the leucosis process progression and permanent lymphocytosis development [9].

But several aspects of metabolism features at the latent stage of the disease, when the process of interaction between the virus and cell-target and combination of their genetic material take place, still little studied. It is somehow connected with the fact that molecular-genetic methods that allow to reveal proviral DNA of the agent are not sufficiently developed in the native science [10]. The improvement of leucosis diagnostics methods is realized using immunochromatographic express-test for determining antibodies to the virus of leucosis in cattle blood serum [11]. A polymerase-chain reaction is widely used for revealing the leucosis virus in cattle [12]. The base of the cattle leucosis diagnostics at the modern stage is the serological research method [13]. The more sensitivity of IEA method at an experimental infection of cattle with leucosis virus was estab- 
lished [14]. The nested PCR analysis for revealing proviral DNA of cattle leucosis virus in blood samples was developed. The offered method is more sensitive comparing with one-stage PCR and allows to reveal more infected animals by $23 \%$ [15]. It is proved, that the feature of the cattle leucosis pathogenesis is DNA virus introduction into the lymphocyte genome of an infected animal that is a cause of the long latent period of the disease [16].

The studies of scientists of the center are realized in the direction of the analysis of regularities of cattle leucosis spreading and factors that condition them. The necessity to introduce new, more effective methods of leucosis diagnostics, first of all IEA and PCR is proved [17]. It was established, that cattle leucosis epizooty can be overcame by the early revelation and elimination of sources of the infection agent and organizational-economic arrangements [18]. The permanent serologic control of susceptible livestock at economies of different subordination provides epizootic welfare at to cattle leucosis [19]. Modern requirements as to cattle breeding welfare at cattle leucosis may be realized only under conditions of the objective estimation of the real epizootic state of cattle breeding in Ukraine [20].

The effective method of a fight against the infectious disease is prophylaxis and treatment by specific means that creates the immunity against it. Such preparations are at the stage of development for today. Variants of inactivated vaccine against cattle leucosis can cause rather high immune response in the immunity system of guinea-pigs (antibodies titre 1:8) in 7 days after the administration [21]. The effect of izamben on the course of the infectious process, caused by VL C in cows' organism was established. The hypodermic use of the preparation in 2,5\% solution in $1,0 \mathrm{~g}$ for $100 \mathrm{~kg}$ of the body mass once a day during 3 days causes the growth of interferon titres in blood serum of studied animals and favors the rise of the level of antibodies to the cattle leucosis virus [22].

\section{Aim}

The study of the effect of "Leucozav" on blood morphological parameters (leukocyte profile) of clinically healthy cows and ones, infected by the leucosis virus.

\section{Materials and Methods}

The studies were carried out in winter on cattle of the Ukrainian black-spotted milk specie. Serological (reaction of immune diffusion (RID)) and immunological (determination of erythrocytes, leukocytes number) research methods were used. To form the control and studied group, blood was taken from cows and studied by the immune diffusion reaction in the agar gel (RID). Petri dishes were placed at the completely horizontal surface. The melt agar-gel was poured in $15 \mathrm{ml}$. After keeping at the room temperature to the complete hardening, holes were cut using a punch, and studied serums and antigen were introduced in them. The control with positive leucosis serum was set at the same time. The reaction took place at the temperature $22-24{ }^{\circ} \mathrm{C} 48$ hours. The presence of distinct lines of precipitation in studied samples testified to the infection of tested animals.

The experiment was set on cows of 3-4 lactation, divided by the analogues principle in four groups by ten animals in each one: the control group (RID-), studied group No. 1 (S1) (RID-), studied group No. 2 (D2) (RID+), studied No. 3 (D3) (RID +). Cows of I group (control - C) that were not administered with the preparation and also studied group No. 2 (S2) at the end of the preparatory period that lasted 20 days were hypodermically administered with the isotonic solution of sodium chloride. Animals of the studied group No. 1 (S1) and studied group No. 3 (D3) were hypodermically administered with "Leucozav" in the dose $2 \mathrm{~cm}^{3}$. The repeated administration of this preparation to cows of the control and studied group took place in 1 month.

\section{Experimental procedures}

Blood for the studies was taken from the jugular vein of cows before administering the studied preparation, in 1 month after its administration and in two weeks after its repeated use (revaccination).

The statistical analysis to the received results was realized using Microsoft Excel program package for personal computers using conventional methods of variation statistics with the assessment of mean (M), error (m) and calculation of differences reliability by Student method.

All manipulations with animals were realized according to the European convention about protection of spinal animals, used for experimental and other scientific aims and Law of Ukraine "On protection of animals from cruel treatment". 


\section{Results}

Taking into account VL C tropism to blood cells, the important value in the study of the leucosis process belongs to the calculation of leukocytes number and determination of the ratio of their separate forms. The results of the study, presented in Table 1, testify that in blood of RID-positive cows the number of leukocytes is more during the whole experiment $(p<0,05)$, than in the control. The administration of "Leucozav" to cows causes the increase of the number of leukocytes in blood. Especially, at 30-th day after the vaccination leukocytes number in blood of animals from D1 and D3 was higher by 16,0 and $63,8 \%(p<0,05)$ respectively, than in cows from the control group. In the following period of researches the tendency to leukocytes number decrease in blood of vaccinated animals was observed. Especially, at 14-th day after the revaccination the number of leukocytes in blood of Rid-negative (S1) and RID-positive cows was respectively by 4,8 and $13,0 \%$ less than before administering "Leucozav". Let's note, that in the given period of the studies there was fixed the decrease of leukocytes number by $24,6 \%$ in blood of cows of D3 group comparing with D2 group. These data testify to the stimulating impact of the studied preparation on leukocytes number of cows up to 30 day age and its inhibiting impact after the revaccination. The increase of leukocytes number in blood of RID-negative vaccinated animals at $30^{\text {th }}$ day after the injection may be caused by the fact that the regular reaction of the organism on the antigen - increase of the general leukocytes number is observed after administering "Leucozav". It is important for specific immunity factors formation.

Table 1

Leukocyte profile of blood of cows at using "Leucozav" ( $M \pm m ; n=4-6)$

\begin{tabular}{|c|c|c|c|c|}
\hline \multirow{2}{*}{ Parameters } & \multirow{2}{*}{ Groups } & \multicolumn{3}{|c|}{ Period of studies } \\
\hline & & Before vaccination & 30 days after vaccination & 14 days after revaccination \\
\hline \multirow{4}{*}{ Leukocytes, G/1 } & $\mathrm{C}$ & $9,38 \pm 1,51$ & $10,63 \pm 1,38$ & $11,50 \pm 1,29$ \\
\hline & S1 & $10,33 \pm 0,60$ & $12,33 \pm 1,01$ & $9,83 \pm 1,45$ \\
\hline & $\mathrm{S} 2$ & $14,42 \pm 2,27$ & $16,58 \pm 2,02 *$ & $18,08 \pm 2,28^{*}$ \\
\hline & $\mathrm{S} 3$ & $15,67 \pm 1,98^{*}$ & $17,42 \pm 2,30^{*}$ & $13,63 \pm 2,17$ \\
\hline \multirow{4}{*}{ Basophils, \% } & $\mathrm{C}$ & $1,5 \pm 0,50$ & 0 & $1,0 \pm 0,00$ \\
\hline & S1 & $1,0 \pm 0,00$ & 0 & 0 \\
\hline & $\mathrm{S} 2$ & $1,0 \pm 0,00$ & $1,33 \pm 0,33$ & $1,0 \pm 0,00$ \\
\hline & $\mathrm{S} 3$ & $1,5 \pm 0,50$ & $1,0 \pm 0,00$ & $1,33 \pm 0,33$ \\
\hline \multirow{4}{*}{ Eosinophils, \% } & $\mathrm{C}$ & $5,25 \pm 0,95$ & $5,0 \pm 0,82$ & $4,25 \pm 0,81$ \\
\hline & $\mathrm{S} 1$ & $4,67 \pm 0,88$ & $4,67 \pm 0,33$ & $5,00 \pm 1,0$ \\
\hline & $\mathrm{S} 2$ & $2,5 \pm 0,65^{*}$ & $2,0 \pm 0,71^{*}$ & $1,8 \pm 0,58^{*}$ \\
\hline & $\mathrm{S} 3$ & $2,25 \pm 0,75^{*}$ & $2,83 \pm 0,42 *$ & $4,17 \pm 0,60^{\#}$ \\
\hline \multirow{4}{*}{ Stick-kernel, \% } & $\mathrm{C}$ & $2,75 \pm 0,75$ & $2,25 \pm 0,95$ & $3,75 \pm 0,75$ \\
\hline & S1 & $3,0 \pm 1,0$ & $2,33 \pm 0,67$ & $3,33 \pm 0,67$ \\
\hline & $\mathrm{S} 2$ & $2,17 \pm 0,48$ & $2,5 \pm 0,43$ & $2,5 \pm 0,43$ \\
\hline & $\mathrm{S} 3$ & $2,20 \pm 0,58$ & $2,33 \pm 0,42$ & $3,0 \pm 0,52$ \\
\hline \multirow{4}{*}{ Segment-kernel, \% } & $\mathrm{C}$ & $27,75 \pm 1,49$ & $27,25 \pm 1,70$ & $28,0 \pm 2,08$ \\
\hline & S1 & $27,0 \pm 2,08$ & $23,0 \pm 1,53$ & $25,67 \pm 1,76$ \\
\hline & $\mathrm{S} 2$ & $21,5 \pm 1,82^{*}$ & $18,0 \pm 1,46^{* *}$ & $15,67 \pm 1,23^{* * *}$ \\
\hline & $\mathrm{S} 3$ & $19,33 \pm 2,60 *$ & $15,5 \pm 1,23 * * *$ & $22,67 \pm 1,52^{\# \#}$ \\
\hline \multirow{4}{*}{ Lymphocytes, \% } & $\mathrm{C}$ & $59,5 \pm 2,33$ & $60,75 \pm 1,65$ & $58,0 \pm 2,35$ \\
\hline & $\mathrm{S} 1$ & $60,67 \pm 1,76$ & $65,0 \pm 1,53$ & $59,00 \pm 1,73$ \\
\hline & $\mathrm{S} 2$ & $70,67 \pm 2,42 *$ & $73,5 \pm 2,14 * * *$ & $76,67 \pm 1,33^{* * *}$ \\
\hline & S3 & $73,00 \pm 3,08^{* *}$ & $75,00 \pm 2,36^{* * *}$ & $63,33 \pm 1,82^{\circ \# \# \#}$ \\
\hline \multirow{4}{*}{ Monocytes, \% } & $\mathrm{C}$ & $4,0 \pm 0,91$ & $4,75 \pm 0,85$ & $5,5 \pm 0,65$ \\
\hline & $\mathrm{S} 1$ & $4,0 \pm 1,53$ & $5,0 \pm 1,0$ & $7,00 \pm 2,08$ \\
\hline & $\mathrm{S} 2$ & $3,5 \pm 0,89$ & $4,0 \pm 0,93$ & $3,17 \pm 0,60^{*}$ \\
\hline & $\mathrm{S} 3$ & $3,83 \pm 0,65$ & $4,0 \pm 0,77$ & $6,17 \pm 1,08^{\#}$ \\
\hline
\end{tabular}

Note: $*-p<0,05 ; * *-p<0,01 ; * * *-p<0,001$ - differences reliability in animals of the studied groups, comparing with the control one; ${ }^{\#}-p<0,05$; \# $-p<0,01$; \#\# $-p<0,001$ - differences reliability between $S 3$ and $S 2$ groups; $C$ (control) - healthy animals; $S 1$ - vaccinated healthy animals; $S 2-R I D^{(+)} ; S 3-R I D^{(+)}$vaccinated 
The great and functionally important group of leukocytes in blood is neutrophils and lymphocytes that are the main immune-competent cells. As it may be seen from the data, given in Table 1, in all periods of the study the number of eosinophils and segment-kernel neutrophils in blood of RID-positive not vaccinated animals is $(\mathrm{p}<0,05-0,001)$, and the number of lymphocytes reliably more than in animals of the control group.

The presented data testify that in animals with the hidden leucosis course was fixed the brightly expressed lymphocytosis $(\mathrm{p}<0,05-0,001)$, that is typical for cattle, infected by VL by the "Leucosis key". It is well-known, that at the change of the stage of leucosis process course, the character of leucosis manifestation in the organism of animals changes too. Especially, at the proviral stage leucosis is usually neutrophilic and at the stage of VL C antibodies creation - lymphocytic. Such changes in the leukogram of RID-positive cows are typical for serologically positive animals at the stage of VL C antibodies creation.

The use of "Leucozav" for RID-positive animals has the normalizing effect on the number of leukocytes and ratio of their separate forms in blood of cows.

\section{Discussion}

"Leucozav" is an experimental preparation. Such means for the treatment and prophylaxis of cattle leucosis are not used in Ukraine. So, the received results of its use for infected animals are especially interesting because of critical epizootic situation as to cattle leucosis.

The use of the studied preparation for animals didn't essentially influence the ratio of separate forms of leukocytes in blood of cows of D1 group. At the same time at 14-th day after the revaccination it caused the decrease of leukocytes number $(p<0,01)$ and increase of the number of eosinophils $(p<0,05)$ and segment-kernel neutrophils $(p<0,01)$ in RID-positive vaccinated cows comparing with infected ones (D2) that were not injected. At the same time in blood of the third studied group after the revaccination was fixed the twice increase $(p<0,05)$ of the number of monocytes comparing to animals of D2 group that testifies to the activation of the phagocytic activity of the cellular link of immunity.

\section{Conclusions}

1. It was established, that the general number of leukocytes in blood of cows, infected by the leucosis virus was more at all stages of the study $(p<0,05)$, than in RID-negative animals. In blood of RID-positive cows was fixed the increase of the number of lymphocytes $(p<0,05-0,001)$ and decrease of the number of eosinophils $(p<0,05)$ and segment-kernel neutrophils $(p<0,05-0,001)$.

2. The use of "Leucozav" for animals didn't essentially influence the general number of leukocytes in blood, but caused the decrease of the lymphocytes number at $14^{\text {th }}$ day after the revaccination $(p<0,01)$ and increase of eosinophils $(p<0,05)$ and segment-kernel neutrophils number $(p<0,01)$ in blood of RID-positive vaccinated cows comparing with infected cows (D2 group) that were not administered with the studied preparation.

3. The administration of "Leucozav" to RID-positive animals normalizes the number of leukocytes and ratio of their separate forms in blood of cows.

\section{Acknowledgments}

We express the great thanks for the participation in the scientific work to the associates of the immunology department of the Institute of animal biology of NAS: d. vet. s., s.r.a. Ogorodnik N. Z., c. biol. s, s.r.a. Kichun I. V., c. biol. s., s.r.a. Broda N. A., c. arg. S., s.r.a. Smolyaninov K. B., c.vet. s. Ratsky M. I., c.vet. s. Mudrak D. I., c. arg. s Matiukha I. O., prof, Yasninsky R. S.

\section{References}

[1] Bessarabov, B. F., Voronin, Y. S. (2007). Infekciyni khvoroby tvaryn [Infectious diseases animals]. Moscow: Kolos, 671.

[2] Enzootic Bovine Leukosis (2012). OIE Terrestrial Manual, 11.

[3] Rodriguez, S. M., Florins, A., Gillet, N., De Brogniez, A., Sanchez-Alcaraz, M. T., Boxus, M. et. al. (2011). Preventive and Therapeutic Strategies for Bovine Leukemia Virus: Lessons for HTLV. Viruses, 3 (12), 1210-1248. doi: 10.3390/v3071210 
[4] Gillet, N., Florins, A., Boxus, M., Burteau, C., Nigro, A., Vandermeers, F. et. al. (2007). Mechanisms of leukemogenesis induced by bovine leukemia virus: prospects for novel anti-retroviral therapies in human. Retrovirology, 4 (1), 18. doi: 10.1186/1742-4690-4-18

[5] Rosewick, N., Momont, M., Durkin, K., Takeda, H., Caiment, F., Cleuter, Y. et. al. (2013). Deep sequencing reveals abundant noncanonical retroviral microRNAs in B-cell leukemia/lymphoma. Proceedings of the National Academy of Sciences, 110 (6), 2306-2311. doi: 10.1073/pnas.1213842110

[6] Polishchuk, L. Z., Riabtseva, O. D., Lukianova, N. Yu., Chekhun, V. F. (2011). Molekuly adhezii ta yikh znachennia pry rozvytku zloiakisnykh pukhlyn [Adhesion molecules and their importance in the development of malignant tumors]. Onkolohyia, 13 (1), 4-11.

[7] Kisera, Ja. V. (2008). Aktyvnist okremykh fermentiv obminu vuhlevodiv krovi u infikovanoi virusom leikozu velykoi rohatoi khudoby [The activity of some enzymes of carbohydrate metabolism in blood leukemia virus infected cattle]. Visnyk Poltavskoi derzhavnoi ahrarnoi akademii [Bulletin of Poltava State Agrarian Academy], 1, 137-139.

[8] Kisera, Ja. V. (2010). Morfofunktsionalni, imunolohichni ta biokhimichni zminy v patohenezi leikozu velykoi rohatoi khudoby [Morphological, functional, immunological and biochemical changes in the pathogenesis of bovine leukemia]. Lviv, 405.

[9] Kisera, Ja. V. (2013). Metabolizm bilkiv u khvoroi leikozom velykoi rohatoi khudoby [Metabolism of proteins in a patient bovine leukemia]. Naukovyi visnyk LNUVMBT imeni S. Z. Hzhytskoho [Scientific Messenger of Lviv National University of Veterinary Medicine and Biotechnologies named after S. Z. Gzhytskyj], 15 (3 (1)), 130-135.

[10] Mandigra, M. S., Liubar, N. V., Udiak, V. M. (2011). Otsenka pryzhyznennoi dyahnostyky leikoz krupnoho rohatoho skota [Evaluation of intravital diagnosis of leukemia of cattle]. NTB Ynstytut byolohyy zhyvotnukh y HNYKY vetpreparatov y kormovukh dobavok [Scientific Technical Bulletin Animal Biology Institute and State Scientific Research Institute for Veterinary medicines and feed additives], 12 (1 (2)), 362-367.

[11] Breus, Yu. V., Nebeshchuk, O. D., Khomenko, Ya. V., Martunenko, D. L., Rubalchenko, D. Yu. (2013). Razrabotka y konstruyrovanye ekspress-testa dlia dyahnostyky leikoza krupnoho rohatoho skota [Development and construction of an express test for the diagnosis of leukemia of cattle]. Kazakhskoho ahrotekhnycheskoho unyversyteta ym. S. Seifullyna [Bulletin of Science of the Kazakh Agrotechnical University named after S. Seifullin], 4 (79), 15-21.

[12] Huliukyn, M. Y., Kozireva, N. H., Lomakyna, N. F., Yvanova, L. A., Lopunov, S. V. (2009). Prymenenye polymeraznoy cepnoy reakcyi (PCR) dlia viyavlenia virusa leykoza KRS [Use of polymerase chain reaction for the detection of bovine leukemia virus]. Veterynarna medycyna [Veterinary medicine], 92, 145-150.

[13] Yvanov, O. V., Yvanova, O. Yu., Fedotov, V. P. (2008). Efektyvnos serolohyceskych metodov issledovania pri leykoze krupnoho rohatoho skota [Effectiveness of serological methods of research in leukemia of cattle]. Veterynarya [Veterinary science], 7, 6-8.

[14] Kisera, Ya. V. (2012). Serolohicni metody diahnostyky leykozu velykoyi rohatoyi chudoby [Serologic methods for diagnosis of bovine leukemia]. Naukovyi visnyk LNUVMBT imeni S. Z. Hzhytskoho [Scientific Messenger of Lviv National University of Veterinary Medicine and Biotechnologies named after S. Z. Gzhytskyy], 14 (3 (53)), 89-93.

[15] Ishchenko, L. M., Spyrydonov, V. H., Melnychuk, S. D., Abramov, A. V., Korol, D. M. (2009). Osoblyvosti pryzhyttievoi diahnostyky leikozu velykoi rohatoi khudoby pry vykorystanni polimeraznoi lantsiuhoi reaktsii [Features of molecular diagnostics of enzootic bovine leucosis by use of polymerase chain reaction]. Veterynarna medytsyna [Veterinary medicine], 92, 218-221.

[16] Ishchenko, L. M., Melnychuk, S. D., Ishchenko, V. D., Sysoliatin, S. V., Spyrydonov, V. H. (2014). Lipidnyi sklad syrovatky krovi ovets za eksperymentalnoho zarazhennia virusom leikozu VRKh [Composition of serum lipid in experimental sheep virus bovine leukemia]. Biolohiia tvaryn [The animal biology], 16 (4), 43-49.

[17] Aranctyi, S. V., Rudiasko, D. O. (2013). Epizootolohicny monitorynh leykozu vrch v Ukrayini, pocynayucy z 2000 roku po osin 2012 roku [Epizootological monitoring bovine leukemia in Ukraine since 2000 to fall 2012]. Visnyk Poltavskoyi derzavnoyi ahrarnoyi akademiy [Journal of Poltava State Agrarian Academy], 1, 94-96. 
[18] Mandyhra, S. S., Nychyk, S. A., Busol, V. O., Liubar, N. V. (2016). Zakonomirnosti poshyrennia leikozu velykoi rohatoi khudoby v Ukraini ta faktory, shcho yoho obumovliuiut [Patterns of spreading bovine leukemia in Ukraine and factors that determine it]. Veterynarna biotekhnolohiia [Veterinary Biotechnology], 28, 173-181.

[19] Gorbatenko, S. K., Shapovalova, O. V. (2013). Leikoz velykoi rohatoi khudoby. Zdobutky ta perspektyvy [Leukemia cattle. Achievements and Perspectives]. Veterynarna medytsyny [Veterinary medicine], 97, 169-172.

[20] Stegniy, B. T., Shapovalova, O. V., Gorbatenko, S. K., Korneykov, A. N., Gorzheev, V. M. (2013). Sovremennyie aspektyi leykoza krupnogo rogatogo skota [Modern aspects of large horned livestock leukemia]. Veterinarna meditsina [Veterinary medicine], 97, 242-255.

[21] Busol, V. O. (2010). Imunohenni kharakterystyky inaktyvovanykh vaktsyn proty leikozu velykoi rohatoi khudoby [Immunogenic properties of inactivated vaccines against bovine leukemia]. Naukovyi visnyk veterynarnoi medytsyny. [Scientific Journal of Veterinary Medicine], 6 (79), 44-46.

[22] Galatiuk, O. Ye., Romanyshyna, T. O., Khmelnytskyi, O. H. (2012). Perspektyvy zastosuvannia izambenu $\mathrm{v}$ hospodarstvakh, neblahopoluchnykh shchodo leikozu velykoi rohatoi khudoby [Prospects of izambenu in farms disadvantaged on bovine leukemia]. Naukovyi visnyk veterynarnoi medytsyny [Scientific Journal of Veterinary Medicine], 9 (92), 41-44. 